\title{
SUD PRAVDE EVROPSKE UNIJE KAO POSLJEDNJA NADA ZA SUNOVRAT VLADAVINE PRAVA U POLJSKOJ - POSEBAN OSVRT NA PRAVOSUDNU REFORMU
}

\begin{abstract}
Jovana TOŠIĆ*
Apstrakt: Posljednja pravosudna reforma u Poljskoj izazvala je mnoštvo reakcija u akademskom pravnom prostoru, budući da zadire i u vladavinu prava kao jedno od fundamentalnih načela Evropske unije. Niz kontraverznih reformi, koje svoje uporište nalaze u političkim ambicijama aktuelnih državnih lidera, razmatrao se i pred Sudom pravde Evropske unije u nekoliko navrata. Sud je u svim slučajevima utvrdio manjkavosti reformisanog poljskog sistema pravosuđa, otišavši čak korak dalje $\mathrm{u}$ tom pravcu primjenom ekstenzivnog metoda tumačenja sopstvene nadležnosti, za razliku od ranijih slučajeva ove vrste u kojima se pretežno bavio tehničkim pitanjima. Iako se Sudu nesporno može pripisati značajan napredak u samom pristupu pojmu i značaju vladavine prava unutar Unije, ne postoji opšta saglasnost relevantnih institucionalnih i političkih aktera povodom poljskog ustavnog pitanja, budući da političke institucije insistiraju na sagledavanju istog kroz prizmu diskriminacije sudija, a ne vladavine prava, iako bi obrnut pristup bio adekvatniji. U narednom periodu očekuje se i konačna presuda SPEU u posljednjem predmetnom slučaju u vezi sa poljskom pravosudnom reformom i diskriminacijom sudija poljskog Vrhovnog suda, što će biti interesantno za posmatranje imajući u vidu nedostatak opšte saglasnosti i saradnje glavnih političkih aktera u cjelokupnom procesu. Trenutna situacija u Poljskoj nesumnjivo može da se posmatra i kao spoljnja i unutrašnja opasnost, te iz tog razloga ova tema zahtjeva veću pozornost u nadolazećem periodu. Kao i u svim prethodnim krizama ove vrste, sve oči su okrenute ka Sudu pravde Evropske unije, kao konačnom arbitru u rješavanju ustavno-pravnih sporova unutar Unije.

Ključne riječi: Sud pravde Evropske unije, ustavno pravo, poljski sistem pravosuđa, vladavina prava, diskriminacija, Evropska unija, Evropska komisija.
\end{abstract}

\footnotetext{
* Autorka je doktorantkinja na Pravnom fakultetu Univerziteta u Beogradu. E-mail: tosicjovana92@gmail.com
} 
Evropsko zakonodavstvo, br. 75/2021

\section{1) UVODNE NAPOMENE}

„Ako svaki ustavni sud svake države članice počne tumačiti šta Evropa može, a šta ne može, onda je to početak kraja."

Aktuelna reforma pravosuđa u Poljskoj počela je u jesen 2015. godine dolaskom na vlast nacionalne konzervativne političke partije Pravo i pravda, koja je državu rapidno uvela u fazu tzv. ustavne krize. ${ }^{2}$ Ono što je karakteristično za seriju kontraverznih sudskih reformi koje su uslijedile od 2015. godine jeste činjenica da predstavljaju produbljenje krize vladavine prava u Evropskoj uniji, koju je na sličan način pokrenula Mađarska nekoliko godina ranije. ${ }^{3}$ Iz tog razloga institucije Evropske unije su opravdano izrazile zabrinutost za nezavisnost i nepristrasnost nacionalnih sudova kao integralnog dijela principa vladavine prava. ${ }^{4}$ Nakon što je Evropska komisija, zajedno sa pojedinim državama članicama, pokrenula pitanje sankcionisanja Poljske za povrede fundamentalnih demokratskih vrijednosti Unije i vladavine prava, ovaj problem je dalje upućen Sudu pravde Evropske unije $\mathrm{Cu}$ daljem tekstu: SPEU ili Sud) na konačno razmatranje i odlučivanje. Sud se sada nalazi u nesvakidašnjoj pravno-političkoj situaciji gdje će, kao glavni arbitar, odlučiti o ishodu bitke za vladavinu prava u Uniji. Kao što je profesor Hess istakao, Sud pravde se i ranije susretao sa problemima političke ili ekonomske prirode, ali primarno iz oblasti suprematije komunitarnog prava (građanska prava) ili integriteta unutrašnjeg tržista, ${ }^{5}$ međutim u ovom slučaju riječ je o znatno osjetljivijem području koje izlazi iz strogo tehničkih okvira i zadire u suštinske vrijednosti komunitarnog prava.

Iz navedenog slijedi glavna dilema autora - da li će Sud razmatrati poljski slučaj u svom dobro poznatom uzdržanom maniru baveći se pitanjima tehničke prirode, ili će se ipak odlučiti za oštriji i konkretniji pristup sagledavajući stvar iz ugla kršenja

\footnotetext{
${ }^{1}$ Bivši premijer Belgije Guy Verhofstadt o sukobu njemačkog Ustavnog suda i Suda pravde Evropske unije povodom odluke Evropske centralne banke o programu kupovine javnog sektora, https://www.euronews.com/2020/05/11/analysis-the-european-court-of-justice-sbitter-spat-with-germany-s-constitutional-court, pristupljeno 30.01.2021.

${ }^{2}$ Vid. Matczak Marcin, "Poland's Constitutional Crisis: Facts and Interpretations", The Foundation for Law, Justice and Society, 2018, pp. 2-9.

${ }^{3} 2020$ Rule of Law Report - Country Chapter on the rule of law situation in Hungary.

4 ",Communication from the Commission to the European Parliament, the Council, the European Economic and Social Committee and the Committee of the Regions"; 2020 Rule of Law Report, https://eur-lex.europa.eu/legal-content/EN/TXT/?qid=1602583951529\&uri=CELEX\%3 A52020DC0580, pristupljeno 30.01.2021.

${ }^{5}$ EU top court gears up for rule-of-law battle (of its life), https://www.politico.eu/article/polandhungary-rule-of-law-court-of-justice-of-the-european-union-gears-up-battle-of-its-life/, pristupljeno 30.01.2021.
} 
vladavine prava. Opšti pravobranilac Sančez Bordona (Sanchez Bordona) smatra da sistemski nedostaci u pogledu sprovođenja vladavine prava u Poljskoj nisu u stanju da liše sudove njihove uloge u državi, uprkos napadu na nezavisnost sudstva. ${ }^{6}$ Kako bi se što preciznije predvidio ishod ove pravno-političke priče koja već neko vrijeme u velikoj mjeri dominira evropskim političko-pravnim prostorom, neophodno je podrobnije ispitati faktičku i formalnu stranu iste, te utvrditi trenutnu poziciju, kao i moć Suda u pogledu sistemskog nepoštovanja principa vladavine prava od strane poljskih vlasti. Kao što to obično biva tokom kriza na teritoriji Evropske unije, sva pažnja je i ovaj put usmjerena ka Sudu pravde Evropske unije kao konačnom arbitru u borbi za oporavak vladavine prava.

\section{2) REFORMA PRAVOSUĐA U POLJSKOJ OD 2015. DO DANAS}

Neposredno nakon preuzimanja vlasti na parlamentarnim izborima održanim 2015. godine, novoformirana poljska vlada, predvođena desničarskom političkom partijom Pravo i pravda (Prawo i Sprawiedliwość), započela je proces rekonstrukcije pravosudnog uređenja zemlje. Glavni cilj ove reforme, koja može da se okarakteriše i kao dikastofobična ${ }^{7}$, jeste eliminacija nezavisnosti i nepristrasnosti pravosudnih organa, kao jednog od najvažnijih uslova za uspostavljanje vladavine prava u državi, a sve u svrhe sprječavanja kontrole pravosuđa od strane izvršne vlasti. Poljsku pravosudnu reformu možemo podijeliti u dvije faze, iako je ovdje riječ o jednom jedinstvenom procesu - period od 2015. do 2017. koji je isključivo usmjeren na funkcionisanje Ustavnog suda i period od 2017. godine koji je fokusiran na osnovne sudove, Nacionalno pravosudno vijeće (tijelo zaduženo za imenovanje sudija i razmatranje njihovih žalbi) i Vrhovni sud, kao konačnu apelacionu instancu za ustavna pitanja. Izmjenom zakona o Ustavnom sudu ${ }^{8}$ omogućena je eliminacija sudija imenovanih od strane prethodne vlasti, prije svega kroz vremensko skraćivanje mandata predsjednika i potpredsjednika suda sa devet na tri godine. Na ovaj način ugrožen je sistem podjele vlasti, prema kojem zakonodavna i izvršna vlast moraju da se uzdrže od bilo kakvog uticaja na sudstvo, naročito u pogledu izbora i imenovanja sudija. ${ }^{9}$ Napad na nezavisnost sudstva nastavila se 2017. godine, kada je izvršna vlast preuzela kontrolu nad Nacionalnim sudskim vijećem

\footnotetext{
${ }^{6}$ Advocate General's Opinion in Joined Cases C-354/20 PPU and C-412/20 PPU, CJEU Press release No. 138/20, https://curia.europa.eu/jcms/upload/docs/application/pdf/2020-11/ cp200138en.pdf, pristupljeno 30.01.2021.

${ }^{7}$ Udruženje tužilaca Srbije dikastofobiju definiše kao opasnu populističku strategiju čiji je cilj širenje straha od sudija i njihovo omalovažavanje, https://www.uts.org.rs/, pristupljeno 31.01.2021.

${ }^{8}$ The Constitutional Tribunal Act of 25 June 2015, https://trybunal.gov.pl/en/about-thetribunal/legal-basis/the-constitutional-tribunal-act/archive, pristupljeno 31.01.2021.

${ }^{9}$ Matteo Mastracci, “Judiciary Saga in Poland: An Affair Torn between European Standards and ECTHR Criteria", Polish Review of International and European Law, Vol. 9, Issue 2, p. 75.
} 
i Vrhovnim sudom i to na vrlo arbitraran način, odnosno restrukturisanjem sudskih organa, kako bi ojačala položaj vladajuće političke partije. Dakle, cjelokupni proces reforme poljskog pravosuđa se odvijao pod izgovorom pravosudne reforme i prava na sopstveni ustavni identitet, koji je ovog puta predstavljen kao suvereno, unutrašnje pravo države članice, što implicira da bi se svaka intervencija Evropske unije smatra ultra vires u tom slučaju. ${ }^{10}$

Nova pravila značila su i promjenu u smislu buduće strukture Nacionalnog sudskog vijeća, nad kojim je uspostavljena potpuna kontrola parlamenta u kojem vladajuća politička stranka uživa većinu. Što se tiče izmjena na nivou Vrhovnog suda, novi zakon je problematičan zbog modifikacije uslova za penzionisanje sudija, koja nalaže spuštanje gornje starosne granice (sa 70 na 65 u slučaju muškaraca i sa 65 na 60 u slučaju žena), što je u konačnici rezultiralo okončanjem mandata velikog broja postojećih sudija, ali i nejednakim postupanjem prema sudijama muškog i ženskog pola. Prema procjeni Vrhovnog suda, preko $37 \%$ sudija je bilo primorano da napusti svoje sudske pozicije zbog novoustanovljenih pravila. ${ }^{11}$ Takođe, isti zakon sadrži odredbu o uslovnom produženju mandata sudija Vrhovnog suda, koji sada na raspolaganju imaju mogućnost podnošenja zahtjeva predsjedniku države za produženje aktivnog sudskog mandata. Međutim, zakonom nisu propisani ni kriterijumi za odlučivanje po ovim zahtjevima, niti su predviđeni odgovarajući vremenski okviri, kao ni mogućnost razmatranja slučaja pred odgovarajućim sudom. Pomenuti zakon karakterističan je i zbog novog oblika sudske revizije pravnosnažnih presuda kroz tzv. vanredne žalbe, što znači da je Vrhovni sud u mogućnosti da ukine, u potpunosti ili djelimično, bilo koju pravnosnažnu presudu ili odluku donesenu od strane poljskih sudova, uključujući i Vrhovni sud, ${ }^{12}$ što nesumnjivo dovodi u pitanje pravnu sigurnost pojedinca.

I najzad, na osnovu zakona o Vrhovnom sudu uspostavljen je novi vid disciplinskog postupka protiv sudija Vrhovnog suda kojim se predsjedniku države (u nekim situacijama i ministru pravde) ostavlja prostor za posredne intervencije u postupak preko disciplinskog službenika kojeg imenuje izvršna vlast, što odstupa od principa nezavisnosti i nepristrasnosti sudstva, a zatim i načela podjele vlasti. Takođe je upitna usklađenost sa pravom na pravično suđenje iz člana 6 stava 1 Evropske konvencije za zaštitu ljudskih prava, ${ }^{13}$ s obzirom na odstranjenje

${ }^{10}$ Dimitry Kochenov, Petra Bard, "The Last Soldier Standing? Courts vs. Politicians and the Rule of Law Crisis in the New Member States of the EU", European Yearbook of Constitutional Law, 2019, p. 255.

11 "Proposal for a Council Decision on the determination of a clear risk of a serious breach by the Republic of Poland of the rule of law", European Commission, https://eur-lex.europa. eu/legal-content/EN/TXT/?uri=CELEX:52017PC0835, pristupljeno 31.01.2021.

${ }^{12}$ Ibid.

${ }^{13}$ Član 6. stav 1. Evropske konvencije za zaštitu ljudskih prava: "Prilikom utvrđivanja građanskih prava i obaveza ili osnovanosti bilo kakve krivične optužbe protiv njega, svako ima pravo na 
proceduralnih garantija $\mathrm{u}$ disciplinskim postupcima protiv sudija. ${ }^{14}$ Najzad, preuzimanje osnovnih sudova od strane vladajućih struktura izvršeno je uspostavljanjem kontrole nad predsjednicima i potpredsjednicima sudova od strane ministra pravde. Imajući u vidu pomenute izmjene u pogledu poljskog pravosuđa, sa razlogom se postavlja pregršt pravnih pitanja, između ostalog iz oblasti ustavnog i radnog prava, kao i pitanja usklađenosti sa fundamentalnim principima Unije poput načela nediskriminacije, jednakosti, vladavine prava i slično. Kao što je Venecijanska komisija istakla u svom izvještaju 2016. godine o stanju vladavine prava i pravosuđa u Poljskoj, ustavnost poljskih zakona više ne može biti zagarantovana nakon ovakvih reformi. ${ }^{15}$

\section{3) PRAVNA PRIRODA PROBLEMA - PITANJE VLADAVINE PRAVA ILI DISKRIMINACIJE?}

Vladavina prava predstavlja jedan od fundamentalnih principa Evropske unije, a zajedno sa ostalim demokratskim vrijednostima, čini sastavni dio člana 2 Ugovora o Evropskoj uniji. ${ }^{16}$ Međutim, ono što razdvaja koncept vladavine prava od ostalih vrijednosti sadržanih u pomenutom članu jeste činjenica da vladavina prava podrazumijeva konstantnu pravosudnu kontrolu unutar države kako bi se "spriječila neograničena hirovitost od strane dominantnog izvora moći" ${ }^{17}$ U novijoj stručnoj literaturi sve češće se pojavljuje termin sunovrat vladavine prava (tzv. rule of law backsliding) kada se raspravlja o aktuelnim ustavnim krizama $\mathrm{u}$ istočnoevropskim zemljama, uključujući i Poljsku. Lorent Peh (Laurent Pech) je na vrlo precizan način ovu pojavu odredio kao proces vršenja uticaja na sudstvo od strane državnih organa, gdje se sistemski ugrožava unutrašnji sistem ravnoteže i

pravično suđenje i javnu raspravu u razumnom roku pred nezavisnim i nepristrasnim, zakonom ustanovljenim sudom", https://vss.sud.rs/sites/default/files/attachments/ EVROPSKA\%20KONVENCIJA\%200\%20LJUDSKIM\%20PRAVIMA\%20SA\%20PROTOKOLIMA. pdf, pristupljeno 01.02.2021.

${ }^{14}$ Proceduralne garantije odnose se na: mogućnost odbacivanja dokaza protiv sudija, mogućnost korištenja dokaza protiv sudija, mogućnost zastare za disciplinske predmete (što znači da bi disciplinski postupak mogao da prevaziđe razumni rok). Vid. Član 108 Zakona o Vrhovnom sudu Poljske, usvojen 8.12.2017.

15 "Poland - Opinion on the Act on the Constitutional Tribunal", adopted by the Venice Commission at its 108th Plenary Session, (Venice, 14-15 October 2016), https://www.venice. coe.int/webforms/documents/?pdf=CDL-AD(2016)026-e\#, pristupljeno 04.02.2021.

${ }^{16}$ Consolidated version of the Treaty on European Union, Article 2: "The Union is founded on the values of respect for human dignity, freedom, democracy, equality, the rule of law and respect for human rights, including the rights of persons belonging to minorities".

${ }^{17}$ Palombella Gianluigi, "The Principled, and Winding, Road to Al-Dulimi; Interpreting the Interpreters", Questions of International Law, Vol 1/2014, p. 18. 
međusobne kontrole tri grane vlasti (sudska, izvršna i zakonodavna) s ciljem slabljenja liberalne demokratske države i dugoročnog učvršćivanja uloge vladajuće političke partije. ${ }^{18}$ Sam koncept vladavine prava duboko je ukorijenjen u pravnoj nauci, sociologiji i međunarodnim odnosima, a nezavisno i nepristrasno pravosuđe pojavljuju se kao centralni elementi istog. ${ }^{19}$ Pojedini autori ističu da nezavisnost sudstva spaja vladavinu prava sa ostalim dijelovima komunitarnog prava i van okvira acquis stricto sensu. ${ }^{20}$

S druge strane, diskriminacija, u širem smislu, predstavlja svako razlikovanje, isključenje ili ograničenje koje dovodi do ugrožavanja ili onemogućavanja ostvarenja, priznanja ili vršenja ljudskih prava u bilo kojoj sferi života i na osnovu nekog ličnog svojstva. ${ }^{21}$ Komisija se izričito pozvala na Direktivu 2006/54 o jednakim mogućnosti žena i muškaraca na polju zapošljavanja i zanimanja ${ }^{22}$ prilikom izražavanja zabrinutosti za različite uslove penzionisanja muškaraca i žena, što je ujedno suprotno i članu 157 Ugovora o funkcionisanju EU. ${ }^{23}$ Međutim, ono što je problematično u stavu Komisije jeste pogrešna formulacija poljskog problema, budući da se pitanje različitog tretmana i diskriminacije sudija koncipira kao primarna briga Evropske unije, a tek u drugom redu kao ugrožavanje nezavisnosti pravosuđa u okviru principa vladavine prava, iako bi ovdje obrnut pristup bio ispravniji i poželjniji. Dakle, diskriminacija na osnovu pola i starosne dobi je samo mali segment (ipak, ne nezanemarljiv) jednog većeg problema, odnosno problema vladavine prava i sistematskog napada na demokratske vrijednosti Unije. Razlog više za pravilnu identifikaciju problema jeste i naknada štete koja se bitno razlikuje u slučajevima diskriminacije i povrede principa

${ }^{18}$ Laurent Pech, "Protecting Polish Judges from the Rulling Party's "Star Chamber, The Court of Justice's interim relief order in Commission v Poland (Case C-791/19 R)", https://verfassungsblog.de/protecting-polish-judges-from-the-ruling-partys-star-chamber/, pristupljeno 27.01.2021.

${ }^{19}$ Član 2. i 19. Ugovora o EU. Primjera radi, videti: Martin Krygier, Adam Czarnota, The Rule of Law after Communism, Routledge 2016; Takođe, vid. Associação Sindical dos Juízes Portugueses, C-64/16 [2018].

${ }^{20}$ Dimitry Kochenov, Petra Bard, "The Last Soldier Standing? Courts vs. Politicians and the Rule of Law Crisis in the New Member States of the EU", op.cit., p. 246.

${ }^{21}$ Krstić Ivana, Zabrana diskriminacije u domaćem i međunarodnom pravu, Pravni fakultet Univerziteta u Beogradu, Beograd 2018, str. 17-18.

22 "Directive 2006/54/EC of the European Parliament and of the Council of 5 July 2006 on the implementation of the principle of equal opportunities and equal treatment of men and women in matters of employment and occupation (recast)," https://eur-lex.europa.eu/legalcontent/EN/TXT/?uri=celex\%3A32006L0054, pristupljeno 07.02.2021.

23 "European Commission statement on the judgment of the European Court of Justice on Poland's Ordinary Courts", https://ec.europa.eu/commission/presscorner/detail/es/ statement_19_6225, pristupljeno 10.02.2021. 
vladavine prava. Ukoliko je u pitanju diskriminacija pojedinaca tj. sudija, na osnovu pola i godina starosti, odšteta u vidu kompenzacije smatrala bi se dovoljnom, a ako je riječ o ugrožavanju vladavine prava, onda kompenzacija kao takva nije dovoljna, te se u tom slučaju zahtjeva povraćaj u pređašnje stanje kroz odstranjivanje svih sistemskih nedostataka u nacionalnom pravosudnom sistemu. Pojedini autori sa razlogom smatraju da su politička tijela Evropske unije pogrešno interpretirala prirodu reforme poljskog pravosuđa, ${ }^{24}$ iako je bilo očigledno da arbitrarna izmjena starosne granice za penzionisanje sudija za glavni cilj ima eliminaciju što većeg broja sudija (koji su na te funkcije postavljeni u nekim drugim političkim vremenima), te formiranje novog sudskog kadra pod patronatom izvršne vlasti. Može se reći da je ovdje riječ o prima facie povredi principa stalnosti sudske funkcije, koja je automatski dovela u pitanje načela zakonitosti, zabrane retroaktivne primjene prava i pravne sigurnosti pojedinca.

S druge strane, bitno je naglasiti da je SPEU znatno unaprijedio svoj pristup problemu vladavine prava u Uniji, naročito ukoliko se osvrnemo na mađarski slučaj Komisija protiv Mađarske $e^{25}$ sa gotovo identičnim činjeničnim stanjem. Za razliku od pomenutog slučaja, gdje je Sud pristupio sa aspekta diskriminacije na osnovu Direktive 2006/54 ${ }^{26}$ iako se radilo o problemu širih razmjera, u slučaju Komisija protiv Poljske, ${ }^{27}$ Sud je ispravio svoje greške iz prošlosti iskoristivši pun potencijal člana 258 Ugovora o funkcionisanju EU ${ }^{28}$ koji predviđa nadležnost Suda u slučaju da država članica ne ispunjava svoje obaveze koje proizilaze iz članstva u Evropskoj uniji. Autor smatra da, iako se poljski slučaj istovremeno odnosi i na sistemsko kršenje vladavine prava i na diskriminaciju pojedinaca u pogledu radnih prava, prirodu problema je neophodno definisati iz šireg ugla, odnosno vladavine prava, koji svakako zahtjeva sveobuhvatniji pristup.

${ }^{24}$ Profesori Laurent Pech i Petra Bard su u više navrata isticali ovaj problem. Primjera radi, vid. Webinar "Rule of Law in Poland 2020: From Bad to Worse" koji je 10.12.2020. organizovala poljska nevladina organizacija - Fondacija FOR (Forum Obywatelskiego Rozwoju).

${ }^{25}$ Commission v. Hungary, Case C-286/12, [2012].

26 "Directive 2006/54/EC of the European Parliament and of the Council of 5 July 2006 on the implementation of the principle of equal opportunities and equal treatment of men and women in matters of employment and occupation (recast).

${ }^{27}$ Commission v. Poland, Case C-619/18, [2018].

${ }^{28}$ Consolidated version of the Treaty on Functioning of the European Union, Article 258, https:// eur-lex.europa.eu/legal-content/EN/TXT/?uri=celex\%3A12012E\%2FTXT, pristupljeno 04. 02.2021. 


\section{4) POSTOJEĆI PRAVNI MEHANIZMI EVROPSKE UNIJE U POGLEDU VLADAVINE PRAVA}

Kao što je prethodno navedeno, sa aspekta acquis- $a$, poljski slučaj zadire prvenstveno u član 2 Ugovora o EU, koji se kao takav značajno razlikuje od ostalih dijelova komunitarnog prava budući da, u slučaju „vječito neposlušnih“ država poput Mađarske i Poljske, povreda ovog člana nema istu težinu kao, primjera radi, povreda članova 260. i 279. Ugovora o funkcionisanju $\mathrm{EU}^{29}$ o privremenim mjerama i finansijskom sankcionisanju države prekršioca. Kada govorimo o fundamentalnim vrijednostima Evropske unije, u koju nesumnjivo spada i vladavina prava, bitno je naglasiti da je Unija prilično nemoćna u pogledu sprovođenja sopstvenih vrijednosti, a često je i neodlučna povodom sadržaja istih. ${ }^{30}$ Ipak, države članice su u obavezi da se pridržavaju člana 2 Ugovora o EU u tom smislu, kao i principa međusobnog priznanja i povjerenja sadržanih u članovima 3. i 4. Ugovora o $\mathrm{EU}^{31} \mathrm{i}$ 67. i 70. Ugovora o funkcionisanju EU. ${ }^{32}$ Sud pravde se na pomenute principe izričito pozvao u svom sada već čuvenom Mišljenju 2/13 o pristupanju Evropske unije Evropskoj konvenciji o ljudskim pravima i osnovnim slobodama ${ }^{33}$, gdje je međusobno povjerenje definisao kao pretpostavku da se u svim državama članicama jednako poštuje i sprovodi komunitarno pravo, uključujući i osnovna ljudska prava kao sistem vrijednosti na kojem Unija počiva. U ovom Mišljenju Sud se takođe dotakao i izuzetnih okolnosti koje ostavljaju prostor za odstupanje od principa uzajamnog povjerenja, iako je priroda ovih odstupanja ostala nejasna. Princip uzajamnog priznanja u kontekstu spornog stanja u poljskom pravosuđu odnosi se na član 4. Ugovora o $\mathrm{EU}^{34} \mathrm{i}$ član 67. stav 4. Ugovora o funkcionisanju $\mathrm{EU}^{35}$ o solidarnosti, uzajamnom povjerenju i priznanju.

${ }^{29}$ Vid. članove 258, 259, 260 i 279 Ugovora o funkcionisanju Evropske unije. Takođe vid. Dimitry Kochenov, Petra Bard, "The Last Soldier Standing? Courts vs. Politicians and the Rule of Law Crisis in the New Member States of the EU", op.cit., p. 264.

${ }^{30}$ Ibid, p. 271.

${ }^{31}$ Consolidated version of the Treaty on European Union, Articles 3 and 4.

${ }^{32}$ Consolidated version of the Treaty on Functioning of the European Union, Articles 67, 70, 81. Više o ovim principima videti: Lars Bay Larsen, "Some Reflections on Mutual Recognition in the Area of Freedom, Security and Justice" in Pascal Cardonnel, Allan Rosas and Nils Wahl (eds.), Constitutionalising the EU judicial system: Essays in Honour of Pernilla Lindh, Oxford, Hart Publishing 2012.

${ }^{33}$ Case Opinion 2/13 of the Court (Full Court) of 18 December 2014, https://eur-lex. europa.eu/legalcontent/EN/TXT/?uri=CELEX\%3A62013CV0002, pristupljeno 06.02.2021.

${ }^{34}$ Consolidated version of the Treaty on European Union, Article 4.

${ }^{35}$ Consolidated version of the Treaty on functioning of the European Union, Article 67(3) and 67 (4). 
Između ostalog, i cjelokupan koncept autonomije prava Evropske unije počiva upravo na ovim principima. 0 tome koliko su ovi principi važni u kontekstu vladavine prava svjedoči i slučaj Aranyosi i Căldăraru pred SPEU gdje je jasno rečeno $\mathrm{da}$, shodno članu 7. Ugovora o EU, ${ }^{36}$ suspenzija principa uzajamnog povjerenja može doći u obzir samo u slučaju ozbiljnog kršenja komunitarnih vrijednosti i načela. Kada je riječ o pomenutom članu 7. Ugovora o EU, isti predstavlja glavni pravni osnov za tužbu pred SPEU protiv Poljske, koju je Komisija nekoliko puta pokrenula zbog ograničavanja nezavisnosti pravosuđa i ugrožavanja sistema podjele vlasti. Bivši predsjednik Komisije Hose Manuel Baroso (Jose Manuel Barosso) svojevremeno je član 7. Ugovora o EU okarakterisao kao tzv. „nuklearnu opciju“37 što dovoljno govori o pravnom potencijalu istog. Što se tiče institucionalnog odgovora na poljsko pitanje, Komisija je ažurno odgovorila na dešavanja u Poljskoj pokrenuvši desetomjesečni dijalog sa Poljskom o navodnim povredama fundamentalnih demokratskih principa u okviru novouspostavljenog mehanizma za kršenje vladavine prava unutar Unije. ${ }^{38}$ Bitno je napomenuti da je ova inicijativa prvo rezultirala Izvještajem o vladavini prava u Poljskoj, kao i smjernicama za poboljšanje opšteg stanja u državi, ${ }^{39}$ što samo po sebi nije napravilo značajne rezultate zbog pravnoneobavezujućeg karaktera.

U pogledu Mehanizma za vladavinu prava koji je usvojen 2014. godine na prijedlog Komisije kao jedan vid praktičnog sprovođenja osnovnih vrijednosti Evropske unije kroz mehanizam sankcija ${ }^{40}$, isti se sa punim pravom može posmatrati kao najistaknutiji i najperspektivniji institucionalni odgovor na pitanje vladavine prava u Uniji. ${ }^{41}$ Ovaj okvirni dokument za oblast vladavine prava definiše sastavne elemente samog koncepta i navodi, između ostalog, nepristrasnost i nezavisnost sudstva, zabranu samovolje izvršnih organa vlasti kao i načelo zakonitosti.

Takođe bitno je istaći da se procedura na osnovu ovog dokumenta može pokrenuti samo u slučaju teških i sistematskih povreda principa vladavine prava, budući da se isti temelji na pretpostavci jednakog poštovanja vladavine prava u

\footnotetext{
${ }^{36}$ Consolidated version of the Treaty on European Union, Article 7(1).

${ }^{37}$ Jose Manuel Barroso (Former President of the European Commission), "State of the Union address 2013", http://europa.eu/rapid/press-release_SPEECH-13-684_en.htm, pristupljeno 05.02.2021.

${ }^{38}$ Više o ovom mehanizmu vid. Rule of Law Framework - background, https://ec.europa.eu/ info/policies/justice-and-fundamental-rights/upholding-rule-law/rule-law/rule-lawframework_en, pristupljeno 31.01.2021.

39 "Rule of Law: Commission issues recommendation to Poland", https://ec.europa.eu/ commission/presscorner/detail/sl/IP_16_2643, pristupljeno 31.01.2021.

${ }^{40}$ Consolidated version of the Treaty on European Union, Article 7(1).

${ }^{41}$ Armin von Bogdandy, Carlino Antpöhler, Michael Ioannidis, "Protecting EU Values - Reverse Solange and the Rule of Law Framework”, MPIL Research Paper Series, No. 2016-04, p. 1.
} 
svim državama članicama. Ipak, problematična je činjenica da je ovdje riječ o smjernicama administrativne tj. proceduralne prirode, što znači da na osnovu pomenutog dokumenta nije moguće primjeniti nikakav oblik sankcije protiv države prekršioca, jer shodno članu 7. Ugovora o EU, posljednju riječ u tom pogledu imaju Savjet EU i Evropski savjet. Prema tome, mnogi autori sa punim pravom kritikuju ovaj dokument iz praktičnih razloga tj. zbog nemogućnosti efektivne primjene. ${ }^{42}$

\section{5) ODGOVOR SPEU NA REFORMU POLJSKOG PRAVOSUĐA: UČENJE NA GREŠKAMA IZ PROŠLOSTI?}

Kada institucije Evropske unije pokažu slabost i nedjelotvornost povodom određenih situacija, svi se reflektori okrenu ka SPEU. Kako bi se što preciznije ispitala pretpostavka da je Sud zaista posljednja nada za sunovrat vladavine prava u Poljskoj, potrebno je utvrditi granice moći Suda spram člana 19 Ugovora o EU ${ }^{43}$ koji se bavi sudskom nadležnošću. Takođe je bitno naglasiti da Sud pravde principu vladavine prava pristupa iz perspektive sopstvene autonomije, kao i autonomije pravnog poretka Evropske unije u odnosu na nacionalna zakonodavstva. ${ }^{44}$ Kao što je već rečeno, poštovanje vladavine prava u Uniji je od suštinskog značaja za principe uzajamnog povjerenja i priznanja u oblasti pravosudne saradnje u krivičnim i građanskim stvarima. Ono što je revolucionarno u pristupu SPEU jeste široko tumačenje pojma nezavisnosti sudstva i uzajamnog povjerenja i priznanja, čime se na određen način osnažuje decentralizovani sistem pravosuđa u Uniji, i to u horizontalnom i vertikalnom pravcu. ${ }^{45}$ Na primjer, u predmetu $L M^{46}$ Sud je definisao nezavisnost sudstva iz spoljne i unutrašnje perspektive. Naime, spoljna perspektiva upućuje na to da nezavisnost sudstva podrazumijeva zaštitu sudija od spoljnih faktora i pritisaka, dok se unutrašnja odnosi na neutralnost i nepristrasnost sudija prema strankama u postupku. U pomenutom predmetu $L M$ Sud je po prvi put proširio set izuzetaka koji se odnose na princip međusobnog povjerenja između

${ }^{42}$ Ibid. Takođe, videti: Dimitry Kochenov, Laurent Pech, "Monitoring and Enforcement of the Rule of Law in the EU: Rhetoric and Reality", European Constitutional Law Review, 2015, Issue 3, p. 512; Dimitry Kochenov, Laurent Pech, "From bad to worse? On the Commission and the Council's rule of law initiatives", http://verfassungsblog.de/bad-worse-commission-councilsrule-law-initiatives/, pristupljeno 05.02.2021.

${ }^{43}$ Consolidated version of the Treaty on European Union, Article 19.

${ }^{44}$ Melanie Smith, "Starring into the abyss: a crisis of the rule of law in the EU", European Law Journal, Vol. 25/2019, p. 566. Više o principu direktne primjene komunitarnog prava videti takođe Van Gend en Loos v Nederlandse Administratie der Belastingen, C-26/62, [1962].

${ }^{45}$ Dimitry Kochenov, Petra Bard, "The Last Soldier Standing? Courts vs. Politicians and the Rule of Law Crisis in the New Member States of the EU", op.cit., p. 243.

${ }^{46}$ Minister for Justice and Equality (Défaillances du système judiciaire), Case C-216/18 PPU, [2018]. 
država članica, prateći na neki način logiku iz prethodno navedenog slučaja Aranyosi i Căldăraru i time uspješno spojivši pravo na pravično suđenje iz člana 6. Evropske konvencije o ljudskim pravima sa principima vladavine prava i nezavisnosti pravosudnih organa. ${ }^{47}$ Drugim riječima, Sud je prepoznao manjkavosti poljskog pravosuđa i opravdao mogućnost suspenzije Evropskog naloga za hapšenje onda kada postoji opravdan rizik od povrede prava na pravično suđenje, što se može smatrati inovativnim pristupom u odnosu na, primjera radi, slučaj Poltorak ${ }^{48}$, gdje su takođe priznata određena odstupanja, ali u znatno užem, proceduralnom smislu.

Shodno tome, možemo reći da se kroz pristup poljskom problemu vladavine prava jasno vidi evolucija sudskog pristupa i to zbog primjene šireg tumačenja postojećeg zakonodavstva, kao i prava na pravično suđenje iz člana 6 EKLJP. ${ }^{49}$ Što se tiče stanja u oblasti vladavine prava u Poljskoj, SPEU je do sada tri puta odlučivao o ovom pitanju na osnovu člana 7. stava 1. Ugovora o $\mathrm{EU}^{50}$ na zahtjev Komisije i ujedno sva tri puta naredio hitno sprovođenje privremenih mjera protiv Poljske. U pogledu nezavisnosti pravosuđa, Sud se prvi put o konkretnom pitanju oglasio u predmetu Komisija protiv Poljske ${ }^{51}$ u vezi sa arbitrarnim izmjenama uslova za penzonisanje sudija Vrhovnog suda, odnosno smanjenja gornje starosne granice na 65 godina (za muškarce) i 60 godina (za žene). Sud je zaključio da su poljske vlasti ugrozile princip stalnosti sudske funkcije koji je neophodan za postizanje nezavisnosti sudstva, te naredio momentalnu obustavu primjene novog zakona. U praktičnom smislu to je značilo da su Poljske vlasti istog trenutka bile u obavezi da situaciju u Vrhovnom sudu vrate u pređašnje stanje, što upućuje na to da je Sud prepoznao i pitanje diskriminacije sudija na osnovu godina starosti i vladavine prava u širem smislu. Samim tim, Sud je izbjegao ponavljanje grešaka iz prošlosti, kao na primjer u mađarskom slučaju ${ }^{52}$, gdje je potpuno identična stvar bila formirana kao diskriminacija na osnovu Direktive 2006/54, a ne pitanje vladavine prava, pa je na taj način „otmica“ mađarskog sudstva od strane vlasti prošla nezapaženo. ${ }^{53}$

\footnotetext{
${ }^{47}$ Videti Mattias Wendel, "Mutual trust, essence and federalism - between consolidating and fragmenting the area of Freedom Security and Justice after LM", European Constitutional Law Review, Volume 15, Issue 1, 2019, p. 26.

${ }^{48}$ Poltorak, C-452/16 PPU, [2016].

${ }^{49}$ Dorval Julie, ,The Principle of Mutual Trust between Member States in the Context of the Rule of Law Crisis", Master Working Paper, Maastricht Centre for European Law, 2020/2, p. 28.

${ }^{50}$ Vid. Commission v. Poland, C-441/17 [2018], Commission v. Poland, C-619/18 [2019], Commission v. Poland, C-791/19 R (case in progress).

${ }^{51}$ Commission v. Poland, C-619/18, [2019].

${ }^{52}$ Commission v. Hungary, C-286/12, [2012].

${ }^{53}$ Dimitry Kochenov, Petra Bard, "The Last Soldier Standing? Courts vs. Politicians and the Rule of Law Crisis in the New Member States of the EU", op.cit., p. 246.
} 
U posljednjem sudskom postupku protiv Poljske ${ }^{54}$ Komisiji se, na osnovu člana 259 Ugovora o funkcionisanju EU, pridružilo i pet država članica (Holandija, Belgija, Danska i Finska) izražavajući zabrinutost povodom reformisanog Disciplinskog vijeća za sudije koji ne ispunjava principe nezavisnosti i nepristrasnosti, te zahtjevajući od Suda da predmet sagleda iz perspektive fundamentalnih vrijednosti Unije i upućujući na povrede člana 19 Ugovora o EU i člana 47 Povelje EU o osnovnim pravima. ${ }^{55} \mathrm{U}$ aprilu 2020. godine Sud je izdao nalog za privremene mjere protiv Poljske u vidu suspenzije Disciplinskog vijeća, gdje je posebno naglasio opasnost od uticaja na nezavisnost sudstva i štete u pogledu komunitarnog pravnog poretka, kao i vladavine prava. ${ }^{56} \mathrm{~S}$ obzirom na revolucionarni pristup Suda problemu poljskog pravosuđa, sa nestrpljenjem se očekuje i posljednja odluka povodom ovog pitanja.

Po svemu sudeći, izvjesno je da će Sud otići korak dalje od mađarskog slučaja, te izradi presude pristupiti sveobuhvatno, ne samo iz perspektive diskriminacije, već i fundamentalnih vrijednosti Unije. Na ovom mjestu svakako je bitno upozoriti na već pomenuti uzdržani manir odlučivanja koji u određenoj mjeri sadrži i političku konotaciju i primarno teži ka političko-pravnoj integraciji i stabilnosti između država članica. Takođe, SPEU nije u mogućnosti da problem tzv. sunovrata vladavine prava riješi samostalno, čak ni uz punu podršku država članica. ${ }^{57} \mathrm{I} u$ slučaju da posljednja presuda protiv Poljske zadovolji sve pravnotehničke aspekte, neophodno je sačekati proces implementacije iste kao i konkretan pomak u saradnji sa poljskim vlastima u tom pravcu, prije nego što se proglasi pobjeda vladavine prava nad nedemokratskim političkim režimima.

Kao što profesor Lorent Peh (Laurent Pech) ističe, sam politički dijalog nije i nikada neće biti dovoljno efikasan način borbe protiv onih koji su doveli do ustavnog coup d'etat, ${ }^{58}$ što znači da jedino konkretne sankcije na osnovu člana 7. Ugovora o EU mogu da urode plodom u ovom slučaju. Autor podržava stav da se u dugoročnom smislu fokus treba preusmjeriti sa vladavine prava na reformu cjelokupne Unije u širem smislu, budući da se nedemokratski nacionalni režimi neće tako lako iskorijeniti. Drugim riječima, svojevrsna politička izolacija država

${ }^{54}$ Commission v. Poland, C-791/19 R, [case in progress].

${ }^{55}$ Videti Charter of Fundamental Rights of the European Union, Article 47: „Right to an effective remedy and to a fair trial", https://eur-lex.europa.eu/legal-content/EN/TXT/?uri=CELEX\% 3A12012P\%2FTXT, pristupljeno 06.02.2021.

${ }^{56}$ Court of Justice of the European Union, Press Release No. 47/2020, https://curia.europa.eu/ jcms/upload/docs/application/pdf/2020-04/cp200047en.pdf, pristupljeno 07.02.2021.

${ }^{57}$ Dimitry Kochenov, Petra Bard, "The Last Soldier Standing? Courts vs. Politicians and the Rule of Law Crisis in the New Member States of the EU", op.cit., p. 249.

${ }^{58}$ Pech Laurent, "Protecting Polish Judges from the Ruling Party's "Star Chamber" The Court of Justice's interim relief order in Commission v Poland (Case C-791/19 R)", op. cit. 
prekršilaca putem službenog postupka zbog povrede komunitarnog prava (ne samo od strane Komisije već i ostalih država članica shodno članu 259. Ugovora o funkcionisanju $\mathrm{EU}^{59}$ ), te izricanje finansijskih sankcija u tom pogledu čine se jedinim izlazom iz trenutne situacije. Istovremeno, SPEU bi trebalo da nastavi sa praktikovanjem sveobuhvatnijeg nadzora nad kompletnim sistemom pravosuđa u Uniji, uključujući i nacionalne sudove država članica. ${ }^{60}$

\section{6) NOVI MEHANIZMI ZA OPSTANAK VLADAVINE PRAVA: PREVIŠE, PREMALO, PREKASNO?}

Unaprijeđen pristup SPEU oblasti vladavine prava u Uniji svakako je značajan ne samo u pravnom, već i političkom kontekstu, budući da se Sud posmatra kao posljednja nada za rješenje aktuelne krize. Ipak, postavlja se pitanje šta slijedi nakon pravnosnažnih sudskih presuda i da li će Evropska unija biti u stanju da sistemski i dugoročno eliminiše pomenute probleme. Na ovom mjestu bitno je podsjetiti na sada već opravdan strah od mađarskog, odnosno poljskog efekta prelivanja (spillover effect) na ostale države članice, što naslućujemo kroz slučaj nesvakidašnjeg sukoba između SPEU i njemačkog saveznog Ustavnog suda o nadležnosti Evropske centralne banke ${ }^{61}$, gdje se njemački sud usprotivio presudi SPEU u vezi sa otkupom državnih obveznica od strane Evropske centralne banke, proglasivši je ultra vires. Povodom ovog slučaja i pitanja odnosa podređenosti i nadređenosti u sistemu pravosuđa u Evropskoj uniji, SPEU se u svojoj izjavi pozvao na primat i direktnu primjenu komunitarnog prava u odnosu na nacionalno pravo naglasivši da razlike u tumačenju validnosti presuda i zakona na nivou EU predstavljaju prijetnju jedinstvu i pravnoj sigurnosti unutar Unije. ${ }^{62}$

U presudi Associcao Sindical dos Juizes Portugueses ${ }^{63}$ SPEU je jasno istakao da nacionalni sudovi nisu u isključivoj nadležnosti država članica, štaviše, države su u obavezi da omoguće nezavisno i nepristrasno funkcionisanje svojih sudova u skladu sa primarnim zakonodavstvom Unije čije sprovođenje nadzire SPEU. Zabrinjavajući je podatak da su mađarske i poljske vlasti presudu njemačkog Ustavnog suda dočekale raširenih ruku i u javnost izašle sa izjavama da je ovo „jedan od najvažnijih

\footnotetext{
${ }^{59}$ Consolidated version of the Treaty on Functioning of the European Union, Article 259: „A Member State which considers that another Member State has failed to fulfil an obligation under the Treaties may bring the matter before the Court of Justice of the European Union."

${ }^{60}$ Dimitry Kochenov, Petra Bard, "The Last Soldier Standing? Courts vs. Politicians and the Rule of Law Crisis in the New Member States of the EU", op.cit., p. 250.

${ }^{61}$ Bundesverfassungsgericht (Judgment of the Second Senate of 05.05.2020), 2 BvR 859/15.

62 "Court of Justice of the European Union, Press Release", No. 58/20, https://curia.europa.eu/ jcms/upload/docs/application/pdf/2020-05/cp200058en.pdf, pristupljeno 08.02.2021.

${ }^{63}$ Associcao Sindical dos Juizes Portugueses, Case C-64/16, [2018].
} 
momenata u istoriji Evropske unije, budući da SPEU nema neograničenu moć" 64 Iako ovakav stav tradicionalno nedemokratskih zemalja poput Poljske i Mađarske ne posjeduje faktičku snagu da ugrozi autoritet SPEU usljed postojanja principa direktne primjene prava EU, ne treba zanemariti njihov politički domašaj i uticaj na ostale države članice sa izraženijim ustavnim identitetima poput Njemačke. Evropska unija bi takođe trebalo da poradi na podrobnijem definisanju vladavine prava unutar svojih granica, ukoliko namjerava da istraje u svojoj borbi za autonomiju i primat prava EU, u skladu sa Mišljenjem SPEU 2/13. Budući da se Evropska konvencija o ljudskim pravima za sada čini jedinim izvorom zajedničkog razumijevanja pojedinih elemenata vladavine prava poput sadržine i osnovnih garantija u okviru konkretnih ljudskih prava zagarantovanih Konvencijom, ${ }^{65}$ ne iznenađuje činjenica da se suštinskim pitanjima u vezi sa nezavisnošću i nepristrasnošću pravosuđa kao dijelovima vladavine prava, za sada efikasno bavi samo Savjet Evrope. ${ }^{66}$

Teoretski gledano, pomenute manjkavosti Unije mogu da se kompenzuju i kroz širok dijapazon presuda Evropskog suda za ljudska prava iz oblasti prava na pravično suđenje i nezavisnosti pravosuđa, uprkos određenim kritikama Venecijanske komisije na račun istih. ${ }^{67}$ Ipak, na nivou prakse to nije tako jednostavno, jer je SPEU vrlo odbramben povodom sopstvene autonomije, kao i autonomije komunitarnog pravnog poretka. Što se tiče novih mehanizama i načina borbe za opstanak vladavine prava u Uniji, možemo reći da isti pate od proceduralnih, pa čak i suštinskih nedostataka usljed političkog neslaganja glavnih aktera ovog procesa.

U tom smislu, bitno je pomenuti da je Parlament nedavno usvojio Uslovni mehanizam za vladavinu prava ${ }^{68}$ sa ciljem zaštite fondova EU od zloupotrebe u

${ }^{64}$ Videti izjavu poljskog premijera (Mateusz Morawiecki) i mađarske ministarke pravde (Judit Varga), https://www.ft.com/content/45ae02ab-56d0-486e-bea5-53ba667198dc, pristupljeno 09.02.2021.

${ }^{65}$ Melanie Smith, "Starring into the abyss: a crisis of the rule of law in the EU", op.cit., p. 566.

${ }^{66}$ Primjera radi, videti: Venice Commission, Rule of Law Checklist, CDL-AD (2016)007, Strasbourg, 18.03.2016, 33.

${ }^{67}$ Venice Commission, Report on the Independence of the Judicial System, Part I: The independence of judges, CDL-AD (2010)004, Strasbourg 16.03.2010.

68 "Proposal for a Regulation of the European Parliament and of the Council on the protection of the Union's budget in case of generalized deficiencies as regards the rule of law in the Member States", https://eur-lex.europa.eu/legal-content/EN/TXT/?uri=CELEX\%3A52018PC0324, pristupljeno 09.02.2021. Takođe videte: "Parliament approves the "rule of law conditionality" for access to EU funds", https://www.europarl.europa.eu/news/en/press-room/20201211 IPR93622/parliament-approves-the-rule-of-law-conditionality-for-access-to-eu-funds, pristupljeno 09.02.2021. 
slučajevima teških povreda principa vladavine prava od strane država članica. Novim mehanizmom predviđa se uskraćivanje finansijskih sredstava državama prekršiocima jer, kako navodi izvjestilac Eider Gardiazabal Rubial, „Evropska unije nije à la carte ustanova u kojoj države članice mogu da zadrže sva svoja prava bez ispunjenja obaveza propisanih članstvom u EU". ${ }^{69}$ Iako se Parlamentu nesumnjivo može pripisati uspjeh zbog usvajanja ovog mehanizma, jer finansijske sankcije i jesu jedino efikasno rješenje, i ovdje se postavlja pitanje praktične primjene istog. Automatska suspenzija finansijskih sredstava nije predviđena, te sam dokument na neki način predstavlja površan politički kompromis sa fokusom na finansijske interese Unije i borbu protiv korupcije, umjesto vladavine prava u širem smislu. ${ }^{70}$ Prema tome, dosadašnji političko-pravni dijalog na relaciji Varšave i Brisela može da se okarakteriše kroz frazu "premalo, previše, prekasno". Istovremeno, i premalo i previše truda je uloženo od strane institucija EU povodom poljskog slučaja, uprkos stalnoj težnji poljskih vlasti ka izgradnji i očuvanju sopstvenog ustavnog identiteta, izolovanog od ostatka komunitarnog prava. Takođe, sa punim pravom se postavlja pitanje da li se kasno pristupilo problemu vladavine prava u Uniji, naročito ako uzmemo u obzir pomenuti njemački slučaj i potencijalnu opasnost od efekta prelivanja na teritoriji ostalih država članica.

\section{7) ZAKLJUČNA RAZMATRANJA}

S obzirom na aktuelna dešavanja u poljskom pravosuđu, može se zaključiti da je dosadašnji odgovor SPEU bio revolucionaran, jer je problem arbitrarne sudske reforme ovaj put sagledan iz šire perspektive koja ide korak dalje od strogo tehničkih pitanja, kao što je ranije bio slučaj. S druge strane, političke institucije EU su pogrešno protumačile prirodu poljskog problema baveći se u prvom redu diskriminacijom sudija, pa tek onda vladavinom prava, iako bi obrnut pristup bio poželjan. Novouspostavljeni mehanizmi koji predviđaju finansijske sankcije za države prekršioce predstavljaju solidno rješenje, iako bi primarni fokus trebalo da se preusmjeri sa isključivo finansijskih interesa na oporavak i očuvanje vladavine prava. Ipak, primjetno je da se unutar Unije konačno formira drugačiji stav povodom pojma sankcija u odnosu na države koje krše svoje članske obaveze, iako je jasno da se tome ne pristupa samo sa namjerom očuvanja fundamentalnih vrijednosti i principa EU. Politički dijalog nije, i nikada neće biti, jedini način sankcionisanja država članica sa nedemokratskim tendencijama.

Takođe, postojeća pravna rješenja unutar Unije čine se dovoljnim za djelotvornu borbu protiv sunovrata vladavine prava, što znači da bi pažnja trebalo da se usmjeri na postupak primjene istih, a ne na iznalaženje novih ideja. Pod time se

\footnotetext{
${ }^{69}$ Ibid.

${ }^{70}$ Videti Webinar "Rule of Law in Poland 2020: From Bad to Worse”, 10.12.2020.
} 
podrazumijeva i efikasna implementacija presuda SPEU, primjena mehanizma sankcija, te službeni postupak zbog povreda komunitarnog prava shodno članu 259 Ugovora o funkcionisanju EU (samim tim i određena politička izolacija države prekršioca ukoliko je riječ o međudržavnom postupku).

Situacija u Poljskoj može da se posmatra istovremeno i kao unutrašnja i spoljašnja opasnost, što neminovno iziskuje sistematičan pristup koji obuhvata posvećeniji angažman i država članica i institucija EU. SPEU jeste važan faktor u situacijama ozbiljnih napada na vladavinu prava, međutim, Sud sam po sebi nije dovoljan, čak i kada u potpunosti iskoristi svoj potencijal kao što je učinjeno u ovom slučaju. Postoji čitav spektar suštinskih problema koji se odnosi na implementaciju sudskih presuda, percipiranje pravne prirode problema od strane ostalih institucija EU, kao i nedovoljnu količinu političkog kompromisa između država članica. Imajući to u vidu, biće interesantno posmatrati dalji tok dešavanja povodom poljskog slučaja tokom predstojeće godine, kao i ishod posljednjeg postupka pred SPEU u vezi sa diskriminacijom sudija poljskog Vrhovnog suda.

\section{8) LITERATURA}

Bay Larsen, Lars, "Some Reflections on Mutual Recognition in the Area of Freedom, Security and Justice" in Pascal Cardonnel, Allan Rosas and Nils Wahl (eds.), Constitutionalising the EU judicial system: Essays in Honour of Pernilla Lindh, Oxford, Hart Publishing 2012;

Dimitry Kochenov, Laurent Pech, "Monitoring and Enforcement of the Rule of Law in the EU: Rhetoric and Reality", European Constitutional Law Review, 2015, Issue 3;

Dorval Julie, „The Principle of Mutual Trust between Member States in the Context of the Rule of Law Crisis", Master Working Paper, Maastricht Centre for European Law, 2020/2;

Kochenov Dimitry, Petra Bard, "The Last Soldier Standing? Courts vs. Politicians and the Rule of Law Crisis in the New Member States of the EU", European Yearbook of Constitutional Law, 2019;

Krstić Ivana, Zabrana diskriminacije u domaćem i međunarodnom pravu, Pravni fakultet Univerziteta u Beogradu, Beograd 2018;

Krygier Martin, Czarnota Adam, The Rule of Law after Communism, Routledge, United Kingdom 2016.

Mastracci Matteo, "Judiciary Saga in Poland: An Affair Torn between European Standards and ECTHR Criteria", Polish Review of International and European Law, Vol. 9, Issue 2;

Matczak Marcin, "Poland's Constitutional Crisis: Facts and Interpretations", The Foundation for Law, Justice and Society, 2018. 
Palombella Gianluigi, "The Principled, and Winding, Road to Al-Dulimi; Interpreting the Interpreters", Questions of International Law, Vol 1/2014.

Smith Melanie, "Starring into the abyss: a crisis of the rule of law in the EU", European Law Journal, Vol. 25/2019;

Von Bogdandy Armin, Antpöhler Carlino, Ioannidis Michael, "Protecting EU Values - Reverse Solange and the Rule of Law Framework", MPIL Research Paper Series, No. 2016-04;

Wendel Mattias, "Mutual trust, essence and federalism - between consolidating and fragmenting the area of Freedom Security and Justice after LM", European Constitutional Law Review, Volume 15, Issue 1.

\section{THE COURT OF JUSTICE OF THE EUROPEAN UNION AS A LAST RESORT OPTION FOR THE RULE OF LAW BACKSLIDING IN POLAND - A SPECIAL REVIEW OF THE POLISH JUDICIAL REFORM}

Summary: The latest judicial reform in Poland has provoked numerous reactions in the academic legal space for threatening the rule of law as one of the founding pillars of the European Union. A series of controversial, politically motivated judicial reforms have been discussed before the Court of Justice of the European Union on several occasions, where the Court successfully identified shortcomings of the reformed Polish judicial system. The Court even went a step further by applying an extensive interpretative method when it comes to its scope of jurisdiction, contrary to the previous cases of this kind where mainly technical issues were at stake. Although the Court has significantly contributed to the protection and preservation of the rule of law principle, the Union is still faced with a lack of general consensus on this matter, as political institutions insist on tackling the Polish question primarily as a discrimination issue, rather than a rule of law issue, even though the reverse approach would be much desirable. The hand-down of a CJEU final judgment in the latest case on Polish judicial reform is expected to take place in the coming period, which will be interesting to observe given the lack of general will and cooperation among the main political actors in fighting the rule of law backsliding in Poland. Finally, the current situation in Poland can certainly be perceived both as an external and internal danger, hence requiring more attention at all levels in the forthcoming period. The CJEU has come under the spotlight once again as a final arbiter of constitutional issues in the Union, as it has always been the case in times of crisis.

Key words: Court of Justice of the European Union, constitutional law, Polish judicial system, rule of law, discrimination, European Union, European Commission. 